\title{
SIGNIFICANCE OF QUERCUS SPECIES IN NUTRITION
}

\author{
Helga Migaskó and Károly Ecseri * \\ Department of Horticulture, Faculty of Horticulture and Rural Development, John von Neumann University, \\ Hungary \\ https://doi.org/10.47833/2020.1.AGR.002
}

Keywords:
functional food
tannin
wild fruit
flour
oak

Article history:

Received 27 Nov 2019

Revised 15 Dec 2019

Accepted 20 Dec 2019

\begin{abstract}
The hidden reserves of flora are often found in front of our eyes. One of these is the genus of oaks, which has significance not only aesthetical, ecological and industrial way, but also in human nutrition and phytotherapy. Acorns use as flour and coffee substitutes, kid delicacy and draft sap can also be consumed. Leaves use as flavoring, and the bark has an important anti-inflammatory, astringent and anti-microbial effect. The fruits also contain unsaturated fatty acids, essential amino acids, carbohydrates, phytosterols and minerals. As ingredient of functional food mentioned polyphenols first of all.
\end{abstract}

\section{Introduction}

Traditional Hungarian wild fruit consumption disappeared in the end of $20^{\text {th }}$ century. The decrease is mainly felt in the lowland areas, but 20-30 plant species are still used in some Transylvanian villages until the present date. Nowadays, the cult of collecting and consuming wild species revived again due to health conscious eating and economic crisis [4]. Of the 236 wild species known and used in the Carpathian Basin, we collected sources for the use of Quercus genus in our work, which is significant in forestry and wood industry.

\section{Application of oak species in Hungary and the world}

Acorns of Quercus robur used to replace coffee or mix with flour for bread making in bad times of 18-19 th $^{\text {th }}$ century in Estonia. The leaves and bark used to flavor lacto-fermented cucumbers and beer like drinks. The storage was solved by freezing and drying until the early $20^{\text {th }}$ century [7].

Quercus species (mainly pedunculate and sessile oaks) used as famine food and kid delicacy similarly in Slovakia [14].

In France, the fruits of Quercus coccifera, Quercus faginea, Quercus petraea and Quercus pyrenaica were also consumed beside pedunculate oak, but the most important was Quercus ilex ssp. ballota. Its acorns used for coffee and flour substitute, boiled, baked and raw. The leafy twigs played a role in the preservation of olive. Its significance was great, more than 20 publications dealt with it, and it has been used since the Neolithic. In this country, the beech tree family (Fagaceae) is the second largest wild fruit family (12\%) after the roses [38].

As a preparatory process of acorns, native Americans peeled the collected fruit, then boiled or baked them. In the western regions of continent were ground firstly the acorns, then washed and cooked them [20]. Soaking is usually done in a pit craved on sandy soil or in a wicker basket with cold or first hot water, for about a day. At the end of the treatment, excess water was filtered. The whole fruit was soaked in running water for several days and then dried and ground. Ash is often

\footnotetext{
* Corresponding author. Tel.: +36-76-517-655

E-mail address: ecseri.karoly@kvk.uni-neumann.hu
} 
used for leaching in eastern America, for example from linden. The usually pre-treatment method was boiling here [19].

In Italy played oak acorn an important role in nutrition already in the Bronze Age. Drying and heat treatment were used to reduce tannin content (Figure 1). Storage is usually done in the soil. The storage period may have ranged from a few weeks to several months. The bitter taste of the seeds decreased during storage. Heat treatment is usually done with hot coal or charcoal, which also used as a pre-treatment to reduce tannin content. Then was crushed and eat it, or ground to flour. On the island of Sardinia, the raw material of acorn flour bread was cooked in a mixture of water and clay or water and ash for several hours. Then removed larger pieces of acorn from the porridge and the reminder used as a pie after thickening. The process was completed when the color of the mixture turned yellow from white. The porridge consumed cold or hot [28].

Mixed with wheat flour tastes more pleasant, then using it alone. There was no difference in sensory testing between pre-treatments (boiling until soft, toasting, and boiling-toasting). According to the study, the preparation method does not play a significant role in the taste of foods made from oak acorn, more likely significant energy and time investment slow down the spread of foods like this. Researchers highlighted that there may be smaller differences in taste between trees due to different ecological factors. It is a surprising result that Czech people evaluated the biscuits made of oak acorn flour in the same way as the bread made of rice flour [35].

In Iran, acorn crushed between stones to remove the liquid bitter tannin compounds. Then ground to flour and soaked or dried in the sun to remove the remaining bitter taste. After soaking, they were dried and baked a pie from it. Pancake like bread (so called "kalg") was baked from it in a pan, mixed with salt and water in bad times. In Turkey, the seeds stored in soil are ground, washed, dried and mixed with sugar and spices. This is called "racahout". A complete bread recipe is published in a doctoral dissertation, which takes two weeks to prepare [18].

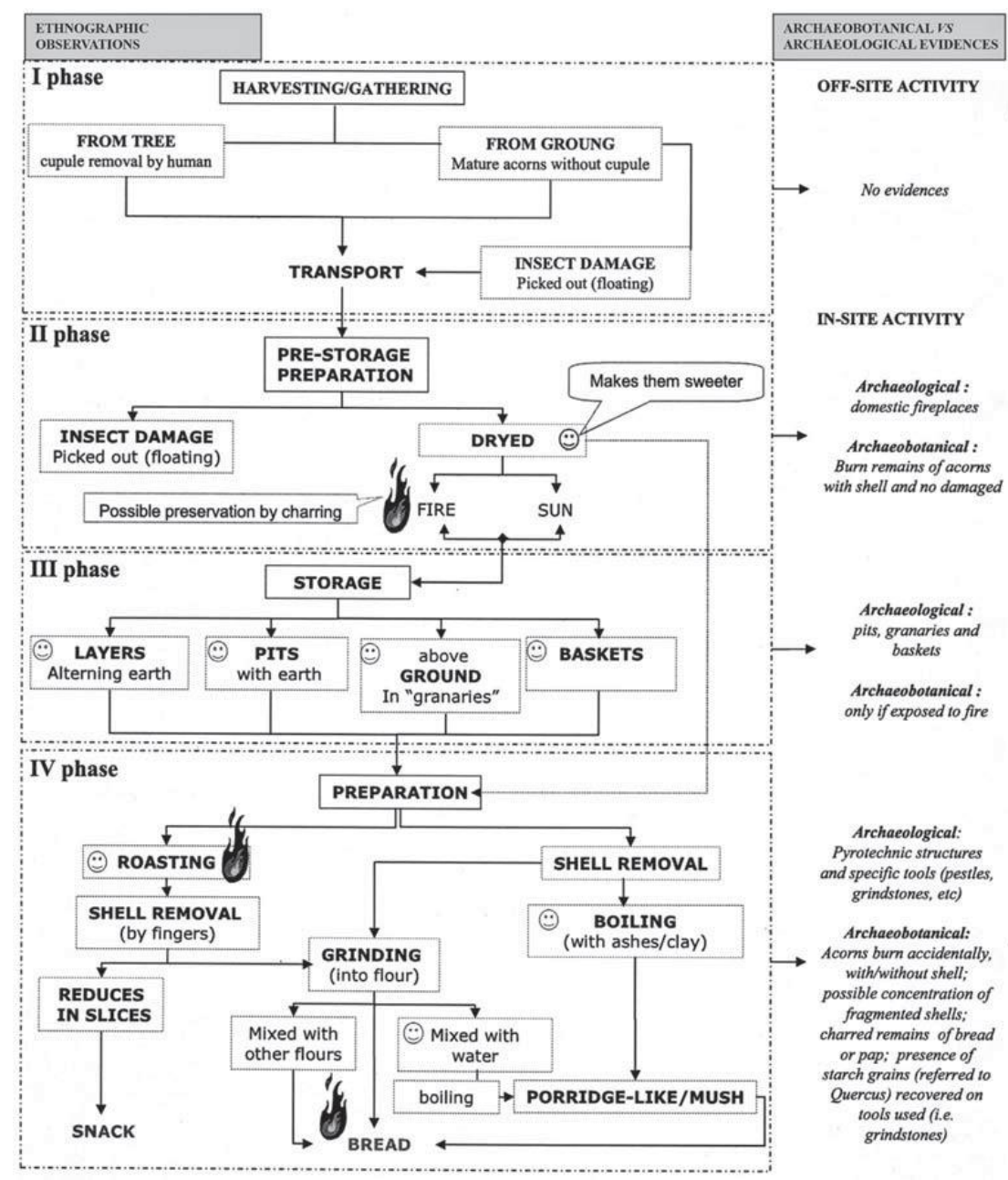




\section{Figure 1. Possible steps of collecting, storing and preparing oak acorns, based on archaeobotanical research [28]}

In Hungary, oak acorn used for coffee [10] and flour substitute, which was dried and mixed to flour, moreover it was used alone for raw material of bread [30]. Other species of Quercus genus were also consumed: the leaves of Quercus petraea, Quercus cerris, Quercus pubescens were put into gherkins for flavoring, the acorns of the pubescent oak were roasted on ember, because the acorns will be sweeter with roasting in the ash. Sap of European turkey oak was drained during the vegetation period [30]. It was so called "stout of shepherds" [4][21]. The extraction of the sap was done by a drill, then elder twig was placed into the hole. It were consumed as a refreshing drink or given to animals for healing [22].

The acorns were also consumed by children as a delicacy. The roasted and coarse-cut fruits were used to replace almonds [16]. Scalding was used to eliminate the bitter taste, according to Hungarian ethnobotanical data. The consumption of dry seeds is outstanding in Hungary, compared to Mediterranean and Scandinavian countries with similar tree composition [4].

The consumption of oak acorn was also observed in Baranya County. In bad years, it were baked on ember, then peeled. Its taste resemble to the roasted chestnut [22].

The roasted, ground oak acorns were also used as a coffee in a village called Kiskovácsvágása, next to Rozsnyó in Slovakia. Bread was made from a mixture of acorn flour and wood fibre [17]. The shell was removed before use, the germ was cut out, and the rest of the acorn was crushed. Then it was dried and finally roasted in a pan in the kitchen or in cauldron on fire. When it cooled, it was broken or ground. After that, the oak coffee was cooked in hot water and then let it settle with cold water. Roasted and ground acorns was cooked with lard and used as a hair growth agent in Southern Transdanubia during World War II [1]. Another way to make acorn coffee is to remove the peel, cut into pieces, toast to dark brown, then grind and toast again [16].

Other oak acorns are also used in human nutrition. In addition to using bread and coffee material in Europe, it was used to produce ink; moreover in China they made starch and alcohol from it [2]. Quercus alba (white oak) has a lower tannin content than the other species of the genus. Indians consumed in the spring (at the beginning of germination) after wintering in soil. Baking was used as a pretreatment method and the seeds were ground to flour. The Mediterranean people also consumed the acorns of Quercus ilex (holly oak) in bed times. It has sweeter taste than the other species [9]. Quercus lobata was a similarly consumed American species in California [30].

The bark and the oak-apples are used in medicine, but the literature also mentions acorns in the case of pedunculate and sessile oaks. Applied externally, it has a local anti-inflammatory, haemostatic and astringent effect due to high tannin content [29]. It also has antimicrobial activity for several viruses, bacteria and fungi [3].

\section{Content values}

The key components of oak acorns are the water-soluble polyphenols, which called tannins (tannin acids). These compounds are important in phytotherapy, but they inhibit the high consumption of oak acorns, because they cause nutrient uptake disorder in intestine, although there is no direct evidence of this [3]. It can damage the intestinal epithelium and liver or kidney tissues. The maximum tannin acid level, which does not cause harmful effects, is $800 \mathrm{mg} / \mathrm{kg} / \mathrm{day}$ in case of rats, and $560 \mathrm{mg}$ for humans [37].

According to recent research, tannin-rich foods (betel nut - Areca catechu, green tea) may have anticarcinogenic effects because they are able to protect cells from the detrimental effects of free radicals, by their antioxidative effects. In addition to external application, antimicrobial activity may play an important role in increasing shelf life of tannin-containing foods. Tannin consumption does not cause nutritional problems in people who eat animal proteins and cereals (wheat, rice, corn, barley) in their diet. Absorption disorders occur in African and Asian peoples who are on a diet based on sorghum, millet or legume species. In the light of these results, consumption in large quantity should be avoided, but in the same time the tannin-containing foods are recommended and suitable for human nutrition in the right form and quantity [3].

Increase of tannin level to $5 \%$ caused no development reduction in rats [11]. 
In a polish study, tannin content was similar in the case of Quercus robur and Quercus petraea (3.39-3.48 \%/ dry matter), while in case of Quercus pubescens this value was very low. Significant differences were found in the size parameters (length, width) and total phenol and tannin content between acorns collected from different regions of the country. The difference can be explained by different habitat conditions or genetic factors [15]. The tannin content in the seed of Quercus robur is $65.6 \mathrm{~g} / \mathrm{kg}$ dry matter according to other sources [34].

Heat treatment can be successfully applied to reduce tannin content. Peeled seeds of Quercus robur and Quercus cerris dried at room temperature and ground to powder. It was the control sample. Part of the powdered flour was heated at $200^{\circ} \mathrm{C}$ for 10 minutes. The amount of non-tannic type phenolic compounds (gallic acid) doubled in the heat treated oak sample. All antioxidant activity, which is strongly correlated with the previous compound, also increased. High temperatures reduced the total phenol and tannin content of treated samples due to the degradation of hydrolysable tannins [32]. The aqueous extract of heat-treated Quercus robur acorn contains $14.93 \%$ polyphenol, $0.27 \%$ gallic acid, and $14.06 \%$ protein. It also contains calcium, magnesium, potassium, phosphorus, iron, copper, zinc and manganese [33]. The tannin content of Quercus cerris has decreased from $11.69 \%$ to $8.55 \%$ with using 15 minute heat treatment at $200^{\circ} \mathrm{C}$, while the antioxidant activity has not changed [31].

Tannin content can also be effectively reduced by using clay. In combination with aqueous solution of powdered acorns or with heat treatment, exerts adsorbent property. Initial tannin value of Quercus rubra can be reduced from 53-55 to 5-10 $\mathrm{mg} / \mathrm{g}$ dry matter [6].

All phenol and gallotannin content were significantly higher in the seed coat of Quercus pubescens and in shelled seeds than in peeled fruits [36].

The crude fatty acid content is between $5-10 \%$ in the fruits of the genus. $60 \%$ of it is oleic acid, $27 \%$ is linoleic acid and $14 \%$ is palmitic acid. This composition is similar to the fatty acid ratio of hazelnut, peanut, and olive tree. The unsaturated/saturated fatty acid ratio is very high $(5: 1)$, which has a positive effect on heart attack prevention. The total sterol content of the examined Mediterranean oaks ranged from 8500 to $11400 \mathrm{mg} / \mathrm{kg}$ [12]. The cholesterol levels were very low (0.1-0.3\%) for Quercus rotundifolia and Quercus suber [13]. Among tocopherols (the isomers of vitamin E) $y$-tocopherol is present in large amounts. The aliphatic alcohol content is 1900-3900 $\mathrm{mg} / \mathrm{kg}$ (six times more than olive oil), and the esterified alcohols is present $1500-2300 \mathrm{mg} / \mathrm{kg}$. There are several compounds in this group with bioactive properties [12].

The pedunculate oak acorn contains $5.2-5.6 \%$ oil ( $\mathrm{g}$ oil $/ 100 \mathrm{~g}$ dry matter). The total fatty acid fraction is $90.8 \%$ of the oil content. The test sample contains 7 fatty acids, mostly unsaturated $(83.7 \%)$. Among fatty acids, oleic acid (44.3\%), linoleic acid $(32.7 \%)$ and palmitic acid (14.8\%) are significant. The oil contains also a small amount of $\alpha$-linoleic acid $(1.8 \%)$, which is one of the omega-3 unsaturated fatty acids and plays an important role in the prevention of cardiovascular disease [26]. The seed of pedunculate oak also contains myristic acid, margarine acid and eicosenoic acid [8].

\section{Other ingredients}

The water content of the pedunculate oak acorns decreases to $40 \%$ at the end of ripening [27]. The carbohydrate content ranges from 26 to $46 \%$ in the genus, depending on the species. The following carbohydrates are found in Quercus robur: inositol, mannitol, galactose, trehalose, xylose, arabinose, glucose, fructose, sucrose. The starch and lignin content increases continually as the fruits ripen [25].

Protein content ranges from 2.75 to $8.44 \%$ in the genus. All 9 essential amino acid are found in the acorn. Pedunculate oak contains high level of valine (234 mg/100 g dry matter), leucine (327 $\mathrm{mg} / 100 \mathrm{~g}$ dry matter) and lysine (207 mg/100 g dry matter). It is important to mention the level of aspartic acid (524 mg/100 g dry matter) and glutamic acid (685 mg/100 g dry matter) [24]. Of the minerals nitrogen $(21.18 \mathrm{mg} / 100 \mathrm{~g}$ dry matter), potassium $(7.87 \mathrm{mg} / 100 \mathrm{~g}$ dry matter), iron (32 $\mu \mathrm{g} / 100 \mathrm{~g}$ dry matter) and zinc $(9.8 \mu \mathrm{g} / 100 \mathrm{~g}$ dry matter) are more significant [23]. 


\section{Conclusion}

Due to these biologically active ingredients (secondary metabolites, mainly polyphenols), researchers specifically recommend the use of oak acorn in the preparation of functional foods [5][31]. The most important goal is to reduce or eliminate bitter taste.

\section{Acknowledgment}

Thank you for the support of the research carried out in the framework of the EFOP-3.6.2-162017-00012 „Developing a functional, healthy and safe food product chain model from field to table in a thematic research network". The project is funded by the Hungarian State and the European Union, co-financed by the European Social Fund, and is part of the Széchenyi 2020 program.

\section{References}

[1] BÖDEI J. (1943): Adatok Zalabaksa gyűjtögető gazdálkodásához. Néprajzi Értesítő. 2:69-96.

[2] ČEMAN, R. (2007): Élő természet - Növényvilág. Földrajzi enciklopédia, rekordok sorozat. Slovart-Print, Pozsony. 176-181. 0.

[3] CHUNG, K.-T., WONG, T. Y., WEI, C-I., HUANG, Y.-W. and LIN, Y. (1998): Tannins and Human Health: A Review. Critical Reviews in Food Science and Nutrition. 38(6): 421-464.

[4] DÉNES A. - PAPP N. - BABAI D. - CZÚCZ B. - MOLNÁR ZS. (2013): Ehető, vadon termő növények és felhasználásuk a Kárpát-medencében élő magyarok körében néprajzi és etnobotanikai kutatások alapján. Dunántúli Dolgozatok (A) Természettudományi Sorozat. 13:35-76.

[5] FERRARI, C. K. B., and TORRES, E. A. F. S. (2003): Biochemical pharmacology of functional foods and prevention of chronic diseases of aging. Biomedicine and Pharmacotherapy 57:251-260

[6] JOHNS, T. and DUQUETTE, M. (1990): Traditional detoxification of acorn bread with clay. Ecology of Food and Nutrition. Vol. 25. pp. 221-228.

[7] KALLE, R., SÖUKAND, R. (2012): Historical ethnobotanical review of wild edible plants of Estonia (1770s-1960s). Acta Societatis Botanicorum Poloniae. 81(4):271-281.

[8] KAROLYI, D., SALAJPAL, K., KIŠ, G., DIKIĆ, M., JURIĆ, I. (2007): Influence of finishing diet on fatty acid profile of longissimus muscle of black slavonian pigs. Agriculture 13 (1): 176-179

[9] KINGSBURY, N. (2016): A természet kincsei. Fák. 150 faj sokrétű bemutatása. Saxum Könyvkiadó, Kína. 172-173. 0.

[10] KÓSA G. (1991): Magvak, termések. Búvár Zsebkönyvek. Móra Ferenc Ifjúsági Könyvkiadó, Budapest. 16. o.

[11] LEASE, E. J. and MITCHELL, J. H. (1940): A study of the tannins of Lespedaza sericea. South Carolina Agricultural Experiment Station Annual Report. 53: 710.

[12] LEON-CAMACHO, M., VIERA-ALCAIDE, I., and VICARIO, I. M. (2004): Acorn (Quercus spp.) fruit lipids: saponifiable and unsaponifiable fractions: a detailed study. Journal of American Oil Chemists Society. 81: 447-453.

[13] LOPES, I. M. G., BERNARDO-GIL, M. G. (2005): Characterisation of acorn oils extracted by hexane and by supercritical carbon dioxide. European Journal of Lipid Science and Technology. 107: 12-19.

[14] ŁUCZAJ, Ł. (2012): Ethnobotanical review of wild edible plants of Slovakia. Acta Societatis Botanicorum Poloniae. 81(4): 245-255.

[15] ŁUCZAJ, Ł., ADAMCZAK, A., DUDA, M. (2014): Tannin content in acorns (Quercus spp.) from Poland. Dendrobiology. 72: 103-111.

[16] MABEY, R. (2004): Vadontermő ennivalók. Trivium Kiadó, Szlovákia. 106. o.

[17] MÁRKUS M. (1941): Gyűjtögetés a Csermosnya völgyében. Néprajzi Értesítő. 33/2: 173-177.

[18] MASON, S. and NESBITT, M. (2009): Acorns as food in southeast Turkey: Implications for prehistoric subsistence in Southwest Asia. IN: A. S. Fairbairn and E. Weiss (2009): From Foragers to Farmers: Papers in Honour of Gordon C. Hillman. OXBOW BOOKS, Oxford and Oakville. pp. 71-85.

[19] MASON, S. L. R. (1992): Acorns in human subsistence. Institute of archeology, Universtiy College. London. pp. 69$70,76$.

[20] MCCORRISTON, J. (1994): Acorn eating and agricultural origins: California ethnographies as analogies for the ancient Near East. Antiquity 68: 97-107.

[21] NAGY CS. (2014): Erdészeti növénytan. Nemzeti Agrárszaktanácsadási, Képzési és Vidékfejlesztési Intézet, Budapest. 35. o.

[22] NAGY R. (1942): Adatok a Baranya megyei Nagyváty növényekkel kapcsolatos szokásaihoz és néphagyományaihoz. Magyar Népnyelv, Debrecen. 4:268-308.

[23] NIKOLIĆ, N., ORLOVIĆ, S., KRSTIĆ, B., KEVREŠAN, Ž. (2006): Variability of acorn nutrient concentrations in pedunculate oak (Quercus robur L.) genotypes. Journal of Forest Science 52 (2): 51-60

[24] ÖZCAN, T. (2006): Total Protein and Amino acid Compositions in the Acorns of Turkish Quercus L. Taxa. Genetic Resources and Crop Evolution 53 (2): 419-429

[25] PALADA-NICOLAU, M., HAUSMAN, J. F. (2001): Comparison between somatic and zygotic embryo development in Quercus robur L. Plant Biosystems 135: 47-55

[26] PETROVIC, S., SOBAJIC, S., RAKIC, S., TOMIC, A., and KUKIC, J. (2004): Investigation of kernel oils of Quercus robur and Quercus cerris. Chemistry of Natural Compounds. 40: 420-422. 
[27] PREWEIN, C., ENDEMANN, M., REINOHL, V., SALAJ, J., SUNDERLIKOVA, V., WILHELM, E. (2006): Physiological and morphological characteristics during development of pedunculate oak (Quercus robur L.) zygotic embryos. Trees 20: 53-60

[28] PRIMAVERA, M., FIORENTINO G. (2013): Acorn gatherers: fruit storage and processing in South-East Italy during the bronze age. Origini XXXV: 211-227.

[29] RÁCZ G. - RÁCZ-KOTILLA E. - SZABÓ L. GY. (2012): Gyógynövények ismerete. A fitoterápia és az alternatív medicina alapjai. Galenus Kiadó, Budapest. 347-348. 0.

[30] RÁCZ J. (2013): Növénynevek enciklopédiája. Az elnevezések eredete, a növények kultúrtörténete és élettani hatása. Tinta Könyvkiadó, Budapest. 740-743. o.

[31] RAKIĆ, S., MALETIĆ, R., PERUNOVIĆ, M., and SVRZIĆ, G. (2004): Influence of thermal treatment on tannin content and antioxidation effect of oak acorn Quercus cerris extract. Journal of Agricultural Sciences. 49: 97-106.

[32] RAKIĆ, S., PETROVIĆ, S., KUKIĆ, J., JADRANIN, M., TEŠEVIĆ, V., POVRENOVIĆ, D., ŠILER-MARINKOVIĆ, V. (2007): Influence of thermal treatment on phenolic compounds and antioxidant properties of oak acorns from Serbia. Food Chemistry. 104:830-834.

[33] RAKIĆ, S., POVRENOVIĆ, D., TEŠEVIĆ V., SIMIĆ, M., MALETIĆ, R. (2006): Oak acorn, polyphenols and antioxidant activity in functional food. Journal of Food Engineering. 74: 416-423.

[34] SALAJPAL, K., KAROLYI, D., BECK, R., KIŠ, G., VICKOVIĆ, I., DIKIĆ, M. and KOVAČIĆ, D. (2004): Effect of acorn (Quercus robur) intake on faecal egg count in outdoor reared black slavonian pig. Acta Agriculturae Slovenica 1: 173-178

[35] ŠÁLKOVÁ, T., DIVIŠOVÁ, M., KADOCHOVÁ, Š., BENEŠ, J., DELAWSKÁ, K., KADLČKOVÁ, E., NĚMEČKOVÁ, L., POKORNÁ, K., VOSKA, V., ŽEMLIČKOVÁ, A. (2011): Acorns as a Food Resource. An Experiment with Acorn Preparation and Taste. Interdisciplinaria Archaeologica. Volume II. Issue 2: 133-141.

[36] SARICICEK, B. Z., \& KILIC, U. (2004): An investigation on determining the nutritive value of oak nuts. Czech Journal of Animal Science. 49: 211-219.

[37] SINGLETON, V.L. and KRATZER, F. H. (1973): Plant Phenolics. In: Toxicants Occurring Naturally in Foods. National Research Council, National Academy of Sciences, Washington, pp. 309-345.

[38] TARDIO, J., PRADO-DE-SANTAYANA, M. and MORALES, R. (2006): Ethnobotanical review of wild edible plants in Spain. Botanical Journal of the Linnean Society. 152:27-71. 